\title{
37. DIAGENESIS OF SILICEOUS SEDIMENTS, PORCELLANITES, AND CHERTS OF THE MOROCCAN BASIN, DEEP SEA DRILLING PROJECT SITES 370, 415, AND 416
}

\author{
Volkher Riech, Bundesanstalt für Geowissenschaften und Rohstoffe, Hannover, West Germany
}

\section{INTRODUCTION}

The main objective of drilling Sites 370 (Leg 41) and 415 and 416 (Leg 50) was to obtain information about the early evolution of the Moroccan Basin. Diagenesis renders the interpretation of the depositional conditions of such sedimentary sequences difficult because it destroys indicators of the environment and causes the formation of new minerals and rocks. The investigation of these diagenetic features is aimed at the recognition of the original metastable primary materials and understanding the relationship between previous depositional environment and the present "diagenetic facies."

We investigated the silica diagenesis in sediments of many North Atlantic DSDP holes (Legs 1-4, 10-12, 14, $41,43,47$ ) with the aid of thin sections, smear slides, scanning electron microscopy, and X-ray diffractometry (von Rad and Rosch, 1974; von Rad et al., 1978; Riech and von Rad, in press; Riech, in press). The dissolution of biogenic opal is the prerequisite for the precipitation of opal-CT (= disordered low-temperature cristobalite-tridymite; Jones and Segnit, 1971) in porcellanites. The rate of transformation of these porcellanites into stable quartz cherts depends on the nature of the surrounding sediments (Lancelot, 1973; Kastner and Keene, 1975). The diagenetic changes of the source materials of silica and the processes leading to the formation of porcellanite are still poorly understood.

Because coring was not continuous and we investigated only a small number of samples (25), we did not expect to find a continuity of diagenetic processes for the Moroccan Basin sites. In addition, the coring technique may have produced cores with an artificially condensed stratigraphic section and some sediments are probably displaced downward (younger sediments in older levels?)

\section{FACIES OF SILICA-BEARING HOST SEDIMENTS}

Mesozoic silica-rich sediments are very rare in the Moroccan Basin sites; thus the Paleogene and lower Miocene sections are most important for our study of silica diagenesis (Figure 1).

Site 415: Relatively high oceanic fertility during the early Miocene resulted in the deposition of nannofossil chalk and alternating zones of siliceous nannofossil marl (Plate 1, Figure 2). Some coquina layers are well cemented. Below a hiatus between the lower Miocene and Eocene very poorly sampled Eocene and Paleocene mudstone contains a small amount of chert. The coarse fraction of one core contains relatively abundant sili- ceous debris which is mainly calcified and associated with recrystallized calcareous aggregates (see Site 415 report, this volume).

The lower Paleocene consists of marlstone with interbeds of chalk and limestone. Moderately well preserved radiolarians form 5 to 10 per cent of the coarse fraction.

Sites 370, 416: The Cenozoic sedimentation at Sites 370 and 416 was probably similar to that of Site 415 : predominantly terrigenous sediments during the Eocene, changing to more hemipelagic mud rich in siliceous microfossils in the early to middle Miocene. Distal turbidity deposits consist of sandstone, siliceous marl, and chalks interbedded with pelagic material in the lower and middle Miocene, upper Oligocene, and Eocene. The radiolarians are well preserved in the Miocene, moderately well preserved in the Oligocene, and poorly preserved in the Eocene sediments. Also radiolarians reworked from older strata occur. The diagenetically lessresistant diatoms were only found in the Miocene samples (Table 1). The turbidites in the middle to lower Eocene unit show an increase in terrigenous components at the expense of pelagic ones. Especially in Site 370, porcellanite nodules are faily common, but only a few radiolarians can be recognized in the host sediments.

Paleocene clay and marlstone is directly underlain by Cenomanian to Barremian hemipelagic claystone. Sponge spicules are occasionally present in the Mesozoic sediments. The Hauterivian to Valanginian turbidites were rapidly deposited and contain a few silicified sediments. From the Tithonian to the early Valanginian, the carbonate influx from shallower sources increased. The cuttings of "chert and porcellanite" reported from these strata were not investigated. Zeolites occur in the Jurassic to Valanginian claystones.

\section{SILICEOUS ORGANISMS AND THEIR MINERALOGICAL ALTERATIONS}

The results on the diagenesis of siliceous organisms in sediments from the Moroccan Basin are given on Table 1 and Figure 1. Except for areas with opal-CT silicification of the matrix, the lower-Miocene organisms are preserved as opal-A ( = unaltered amorphous opal; Jones and Segnit, 1971). All smear slides contained weakly or strongly etched specimens. The surfaces of some of the allegedly solution-resistant sponge spicules are pitted, whereas the associated "less stable" diatoms and silicoflagellates are often well preserved. The presence of biogenic opal-A in the upper-Oligocene sediments of Core 416A-3, close to an inferred mid-Tertiary hiatis, is conspicuous because these organisms, which show no opal-CT formation, occur 150 or 200 meters 

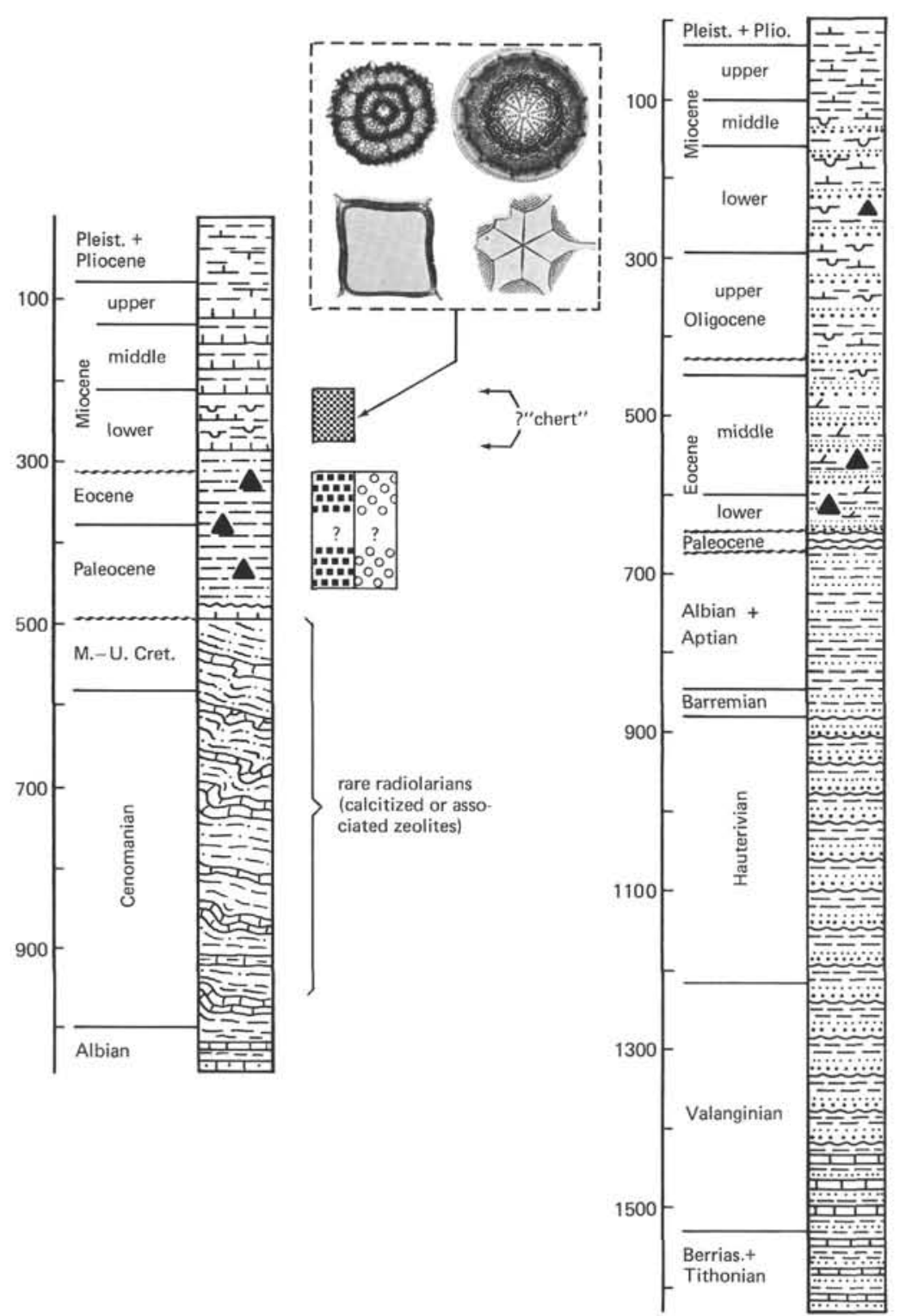

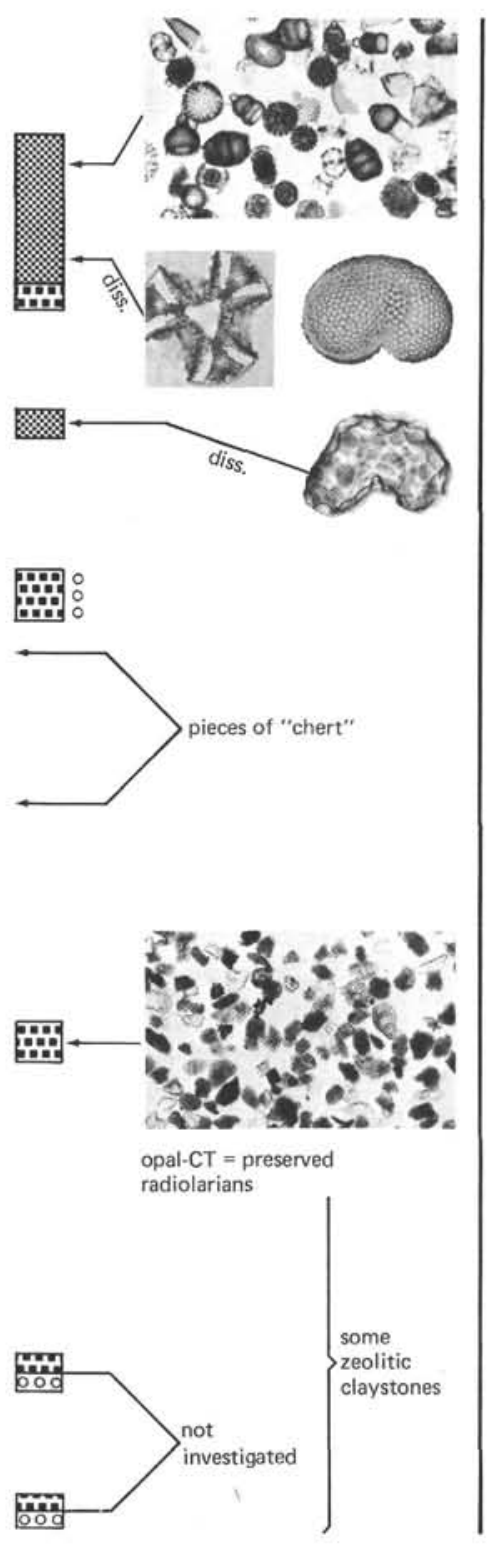

曋望。

W.

III- - diatoms/rads: replaced by

- quartzified rads with

well preserved skeletons

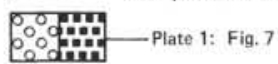

siliceous organisms: opal-A
porcellanites
diss. = distinct dissolution of
siliceous skeletons

Figure 1. Preservation of siliceous organisms and the formation of porcellanites and cherts in the Moroccan Basin sites. 
TABLE 1

Silica Diagenesis in the Moroccan Basin, Sites 370, 415, and 416

\begin{tabular}{|c|c|c|c|c|c|c|c|c|c|c|c|}
\hline \multirow[b]{2}{*}{$\begin{array}{c}\text { Sample } \\
\text { (Interval in cm) }\end{array}$} & \multirow[b]{2}{*}{ Stratigraphy } & \multirow[b]{2}{*}{$\begin{array}{l}\text { Depth } \\
\text { (m) }\end{array}$} & \multirow[b]{2}{*}{ Lithology } & \multicolumn{4}{|c|}{ Siliceous Organisms } & \multicolumn{4}{|c|}{ Formation of Authigenic } \\
\hline & & & & $\begin{array}{l}\text { Content } \\
(\%)\end{array}$ & Fossil Groups & $\begin{array}{l}\text { Disso- } \\
\text { lution }\end{array}$ & $\mathrm{SiO}_{2}$ Phase & $\begin{array}{l}\text { Opal- } \\
\text { CT }\end{array}$ & Quartz & $\begin{array}{l}\text { Zeo- } \\
\text { lites }\end{array}$ & $\begin{array}{l}\text { Clay } \\
\text { Minerals }\end{array}$ \\
\hline $415-4-5,10-12$ & Lower Miocene & 215 & $\begin{array}{l}\text { Foraminifer-nannofossil } \\
\text { chalk }\end{array}$ & 1 & $r>s s>d$ & $\mathrm{x}$ & A & & & & \\
\hline $415-4-5,66-67$ & Lower Miocene & 215 & $\begin{array}{l}\text { Siliceous-debris-bearing } \\
\text { chalk }\end{array}$ & 20 & $\mathrm{~d} \approx \mathrm{ss} \approx \mathrm{I}(\gg \mathrm{si})$ & (x) & A & & & & \\
\hline $415-5-3,50-51$ & Lower Miocene & 275 & Siliceous marl & 20 & $\mathrm{~d}>\mathrm{r}>\mathrm{ss}(>\mathrm{si})$ & $x$ & A & & & & \\
\hline $415-5-3,100-101$ & Lower Miocene & 275 & Siliceous marl & 20 & $\mathrm{~d}>\mathrm{r}>\mathrm{ss}(>\mathrm{si})$ & $?$ & A & & & & ?x \\
\hline $416 \mathrm{~A}-1-2,9-10$ & Middle Miocene & 155 & Marly nannofossil chalk & $<1$ & $r \approx s s(>d)$ & $\mathrm{x}$ & A & & & (x) & \\
\hline $370-4-2,0-2$ & Lower Miocene & 218 & $\begin{array}{l}\text { Porcellaneous nannofossil } \\
\text { marl }\end{array}$ & $10-? 20$ & $d>r ?(>s s)$ & & CT & $x x$ & $\mathrm{x}$ & & \\
\hline $416 \mathrm{~A}-2-1,19-21$ & Lower Miocene & 298 & Slightly siliceous marl & 10 & $\mathrm{r} \approx \mathrm{ss}>\mathrm{d}(>\mathrm{si})$ & $\mathrm{x}$ & A & & & & \\
\hline $416 \mathrm{~A}-2-3,140-141$ & Lower Miocene & 306 & $\begin{array}{l}\text { Nannofossil chalk with } \\
\text { radiolarians }\end{array}$ & 4 & $r$ ss (>d) & $\mathrm{xx}$ & A & & & & \\
\hline $416 \mathrm{~A} \cdot 2, \mathrm{CC}$ & Lower Miocene & 307.5 & $\begin{array}{l}\text { Calcareous porcellanite } \\
\text { with dolo. thombs }\end{array}$ & 2 & ss (\$r) & & $\mathrm{Q}(? \mathrm{CT})$ & $\mathrm{xxx}$ & $\mathrm{x}$ & & \\
\hline $370-5, \mathrm{CC}$ & Upper Oligocene & 330 & $\begin{array}{l}\text { Porcellanite with aggregate } \\
\text { polarization and dolo. } \\
\text { rhombs }\end{array}$ & 5 & $\mathrm{r}(\gg \mathrm{ss})$ & $\mathrm{x}$ & $\mathrm{CT}, \mathrm{Q}$ & $x x x$ & $\mathrm{x}$ & & $\begin{array}{l}\text { ?xx } \\
\text { (palygorskite, } \\
\text { sepiolite) }\end{array}$ \\
\hline $416 \mathrm{~A}-3-1,111-112$ & Upper Oligocene & 450 & Marl with sponge spicules & 5 & $s s>1$ & $x x x$ & A & & & & \\
\hline $416 \mathrm{~A}-3-2,149-150$ & Upper Oligocene & 450 & $\begin{array}{l}\text { Slightly siliceous marl with } \\
\text { clayey microlenses }\end{array}$ & 8 & $s s>r$ & $x x$ & A & & $(\mathrm{x})$ & $\mathrm{x}$ & $\mathrm{x}$ \\
\hline $370-12-2,32-34$ & Middle Eocene & 540 & $\begin{array}{l}\text { Silica-cemented pebble } \\
\text { conglomerate }\end{array}$ & 2 & $\mathrm{r}$ & $?$ & CT,Q & $\mathrm{xx}$ & $\mathrm{xx}$ & & \\
\hline $370-15-1,42-44$ & Middle Eocene & 588 & $\begin{array}{l}\text { Laminated quartz chert } \\
\text { with porcellanite relics }\end{array}$ & & & & & {$[\mathrm{xxx}]$} & $\mathrm{XXX}$ & & \\
\hline $416 \mathrm{~A}-4-1,20$ & L.-M. Eocene & 610 & $\begin{array}{l}\text { Porcellanite with quartz- } \\
\text { cemented pores }\end{array}$ & $?$ & $\begin{array}{l}\text { Quartz- } \\
\text { cemented } \\
\text { ghosts }\end{array}$ & $? \mathrm{xx}$ & & $\mathrm{xxx}$ & $\mathrm{xx}$ & & \\
\hline $\begin{array}{l}\begin{array}{l}416 \mathrm{~A}-4-1 \\
\text { clast } 3\end{array}\end{array}$ & L.-M. Eocene & 610 & $\begin{array}{l}\text { Porcellanite with aggregate } \\
\text { polarization, quartz- } \\
\text { cemented fractures, and } \\
\text { dolo. rhombs }\end{array}$ & $?$ & & & & $\mathrm{xxx}$ & $\mathrm{x}$ & & ?x (palygorskite) \\
\hline \multirow[t]{2}{*}{$370-17-2,23-25$} & Lower Eocene & 618 & $\begin{array}{l}\text { a) Porcellaneous claystone } \\
\text { with aggregate } \\
\text { polarization }\end{array}$ & 2 & $\mathrm{r}$ & $\mathrm{x}$ & CT,Q & $\mathrm{xx}$ & (x) & & ?x \\
\hline & & & $\begin{array}{l}\text { b) Transitions between } \\
\text { porcel. and chert }\end{array}$ & $5-? 10$ & $\mathrm{r}$ & $?$ & $\mathrm{CT}, \mathrm{Q}$ & {$[x x x]$} & $\mathrm{xXX}$ & & \\
\hline $416 \mathrm{~A}-5-1,57-59$ & Lower Eocene & 755 & $\begin{array}{l}\text { Muddy porcellanite with } \\
\text { dolo. rhombs }\end{array}$ & ? & & & & $x \times x$ & $x$ & & \\
\hline $416 \mathrm{~A}-8-1,50-51$ & Hauterivian & 1095 & $\begin{array}{l}\text { Cuttings of mudstone } \\
\text { and porcellanite }\end{array}$ & 1 & r $\gg$ ss & $?$ & CT(Q) & $x x x$ & (x) & $\mathrm{x}$ & $?$ \\
\hline $416 \mathrm{~A}-8-5,41-42$ & Hauterivian & 1115 & $\begin{array}{l}\text { Slightly porcellaneous } \\
\text { mudstone }\end{array}$ & 10 & $\mathrm{r}$ & $?$ & CT & $\mathrm{xx}$ & & $\mathrm{x}$ & $? \mathrm{x}$ \\
\hline
\end{tabular}

Note: $\mathrm{A}=$ opal- $\mathrm{A}, \mathrm{CT}=$ opal-CT, $\mathrm{Q}=$ quartz; $\mathrm{r}=$ radiolarians, $\mathrm{d}=$ diatoms, $s \mathrm{~s}=$ sponge spicules, $\mathrm{si}=$ silicoflagellates; $(\mathrm{x})=$ very weak, $\mathrm{x}=$ weak, $\mathrm{xx}=$ moderate, $\mathrm{xxx}=$ strong; $\mathrm{X}=$ quartz formed from an opal-CT precursor; $[\mathrm{xxx}]=$ former opal-CT now transformed into quartz.

below the youngest porcellanites of Sites 416 or 370 (Figure 1). Here, the silica dissolution is very pronounced: diatoms and silicoflagellates are missing, the assemblage has a high sponge spicule/radiolarian ratio, and the remaining siliceous fossils have highly etched surfaces. In the upper part of Figure 1 (Site 416) two bean-shaped sponge microscleres are shown, the lower one from Core $416 \mathrm{~A}-3$ is highly corroded. Many siliceous fossils and other particles are pyritized. Some radiolarian residues are filled by aggregates of lath-like zeolites(?). A silica-dissolution facies with corroded remains of diatoms occurs in the lower Miocene of Core 416A-2 (Figure 1, center top). Reworked Oligocene radiolarians are also present. The discoasters in this chalk sample have strong calcitic overgrowths.

The youngest opal-CT-replaced siliceous organisms occur in lower-Miocene porcellaneous nannofossil marl (Site 370, Table 1). According to our experience, opal-A is never preserved in genuine porcellanites. This is also true for all silicified sediments of Leg 50 which contain at least opal-CT (Plate 1, Figure 6) or microfossils which have been transformed into quartz. In the porcellanite of Sample 416A-2, CC (lower Miocene), sponge spicules are already replaced by quartz. In Sample $370-12-2,32 \mathrm{~cm}$, quartzified but well-preserved radiolarians could be exsolved from a porcellanitic matrix of a middle-Eocene silica-cemented pebble conglomerate with $\mathrm{H}_{2} \mathrm{SiF}_{6}$ (Plate 1, Figure 8). However, the silification of the matrix is not a prerequisite for the transformation of skeletal opal-A into opal-CT. Rarely, radiolarians are present in the Cenomanian sequence of Site 415. According to the shipboard investigations, they are zeolite-filled or calcitized.

\section{SILICIFIED SEDIMENTS}

In most cases, opal-CT-rich porcellanites and quartz cherts (nomenclature after von Rad et al., 1978) can only be distinguished under the polarizing microscope. 
Therefore the petrographic descriptions made aboard ship on the basis of macroscopic inspection usually cannot be applied.

The silicified rocks of Sites 370 and $416^{1}$ are mainly porcellanites which occur in strata as young as the lower Miocene and, as known from many sites around the world, are most common in middle- to lower-Eocene sequences. Transitional stages between porcellanites and quartz cherts were especially distinct in the Eocene of Site 370, whereas old (Hauterivian) porcellanites from Site 416 contain almost no diagenetic quartz (Table 1) and look rather "immature."

The youngest porcellanites occur at a sub-bottom depth of 218 meters, within a lower-Miocene alternation of radiolarian-bearing nannofossil clay and nannofossil marl. Sample 370-4-2, $2 \mathrm{~cm}$ contains about 15 per cent poorly preserved diatoms and radiolarians and consists of 50 per cent opal-CT. The opaline skeletons of the unsilicified host sediments are better preserved and still consist of the original opal-A.

The porcellanites of lower-Miocene Sample 416A-2, $\mathrm{CC}$ are diffusely silicified nannofossil chalk with 10 per cent dolomite rhombohedra. Diagenetic quartz replaces the few sponge spicules and foraminifer walls, or cements their cavities. The abundant diatoms, radiolarians, and sponge spicules in the diagenetically less-altered host sediments still consist of amorphous opal, but are in part significantly etched (Table 1; see also Heath and Moberly, 1971).

The porcellanites which are associated with Oligocene calcareous silty clay (Sample 370-5, CC) are either opal-CT-cemented fine sandstone (with glauconite and shell fragments) or clayey radiolarian porcellanite with 10 per cent palygorskite-sepiolite and a distinct "aggregate polarization" (von Rad et al., 1978). The scattered carbonate rhombohedra (Plate 1, Figure 3) are magnesium-free in their center, but magnesium-rich near the outer rims. After etching with HF many nannofossils and radiolarians can be recognized under the scanning electron microscope (Plate 1, Figure 4). On the basis of energy-dispersive X-ray analyses, the coccoliths are free of calcium (silicified?).

A 40-cm-thick silica-cemented pebble conglomerate (Section 370-12-2) is an exceptional lithotype. The interstices between the pebbles are cemented by two generations of cement: (1) precipitation of opal-CT along the cavity margins, followed by (2) crystallization of chalcedony in the remaining central pore space. The pebbles themselves contain silicified microfossils; some were transformed after deposition (?) into porcellanites.

A porcellanite of Site 416 (Section 416A-4-1, clast 3) which has a heterogeneous fabric belongs to the same stratigraphic level as the conglomerate, described above. This former calcareous mudstone was probably brecciated during syndepositional slumping and deposited as a pebbly mudstone after a short transport, per-

\footnotetext{
${ }^{1}$ No material was investigated from Site 415 , where silicified rocks were described from Samples $415-4-2,25-50 \mathrm{~cm}, 415-5, \mathrm{CC}$, and 415A-1, CC.
}

haps as a debris flow. Subsequently, the clayey matrix and the intraclasts were impregnated by opal-CT. The high permeability of this redeposited sediment probably favored its penetration by silica-saturated pore waters; this caused the precipitation of opal-CT, despite the apparent lack of siliceous organisms as source material.

The Eocene porcellanites of Site 416 contain only accessory quartz in the form of pore cement (Table 1), whereas the corresponding rocks of Site 370 have transitional phases between the opal-CT matrix and quartz (Plate 1, Figure 7), indicating their higher diagenetic maturity (see von Rad et al., 1978).

Only a few samples of the Hauterivian (Core 416A-8) could be investigated from the Mesozoic silicified rocks of Site 416 (Figure 1). These are diagenetically immature, porcellaneous mudstone, with radiolarians that are completely filled by opal-CT (Plate 1, Figure 6). Some of these semiconsolidated rocks contain globulose masses of opal-CT lepispheres (Florke et al., 1976) in the finest size fraction after distintegration. Locally, they contain abundant montmorillonite which is probably responsible for the "aggregate polarization" of these rocks.

\section{SUMMARY AND CONCLUSIONS}

The fair or poor preservation of siliceous shells can be caused by two different processes: (1) corrosion of mineralogically unaltered tests (opal-A), (2) alteration of the original opal-A to opal-CT (and later to quartz) with synchronous overgrowth of additional opal-CT, zeolites, and authigenic clay minerals. This causes a thickening of the fossil tests and the destruction of the skeletal microstructure.

In the Moroccan Basin sites the original opal-A extends down into the "porcellanite zone" (lower Miocene and older). Within a 200 -meter-thick section, sediments with unaltered skeletal opal alternate with opalCT-rich porcellanites. As elsewhere, the porcellanite chert occurrences in the Moroccan Basin sites indicate periods of significant production, deposition, and preservation of siliceous organisms. Silicified sediments were found in 20 - to 140 -m.y.-old strata at burial depths of 200 to 1600 meters. Apparently, the porcellanites in the Miocene strata are still forming. Since the biogenous opal of these host rocks is mostly unaltered, these rocks possess a high "diagenetic potential," i.e., they will be progressively silicified, given more time and greater burial depth.

The factors which control the initial precipitation of opal-CT in precursor porcellanites are still insufficiently known (Kastner et al., 1977). If we compare the lowerMiocene siliceous sediments of various DSDP sites off the northwest African coast, we see that a burial depth of at least $\mathbf{2 0 0}$ meters is necessary to form porcellanites. An enhancement of the opal-CT precipitation in $\mathrm{CaCO}_{3}$ rich sediments, as found in experiments by Kastner et al. (1977), was not verified by our investigations. We agree with these authors, however, that porcellanites are more rapidly altered into quartz cherts in a carbonate-rich environment. For this reason, the Hauterivian porcellanites interbedded with carbonate-poor 
mudstones (Site 416) have a higher diagenetic potential and lower maturity than the porcellanites and cherts of the more calcareous Eocene rocks (Site 370). There are no strict depth limitations for the stability of opal-A, opal-CT, and quartz, which overlap each other considerably in their vertical range (see also Bramlette, 1946; Keene, 1975). Such discontinuous diagenetic processes are controlled by lithofacies and physical sediment characteristics and are similar to processes in carbonate diagenesis.

A general comparison of silica and carbonate diagenesis indicates that calcitic and dolomitic alterations (overgrowth of nannofossils, dolomite rhombohedra, cementation of coquinas) take less time than mineralogical alterations of siliceous organisms, or precipitation of silica or silicates from solution. One of the causes for this difference might be the comparatively slow increase of the $\mathrm{Si}(\mathrm{OH})_{4}$ concentrations within the interstitial waters during early diagenesis. If enough $\mathrm{SiO}_{2}$ cannot be mobilized, the pore solutions do not reach saturation with respect to the precipitation of opal-CT. However, in these cases minor amounts of authigenic quartz, zeolites, or clay minerals can be formed. The slightly siliceous marl of Sample 416A-3-2, $150 \mathrm{~cm}$ contains corroded siliceous organisms, very porly preserved zeolitefilled radiolarians, and burrows (Plate 1, Figure 1) which are probably filled by authigenic montmorillonite and palygorskite. Hence, this microfacies is a good example of authigenesis of silicates at low silica concentrations in the pore solutions.

\section{ACKNOWLEDGMENTS}

This study was supported by a grant of the Deutsche Forschungsgemeinschaft $(\mathrm{Ra} 191 / 6+7)$ for the investigation of North Atlantic deep-sea cherts. I am very grateful to H. Rosch (Hannover) for contributing semiquantitative X-ray-diffraction analyses of 15 samples. U. von Rad (Hannover) reviewed and translated the manuscript.

\section{REFERENCES}

Bramlette, M. N., 1946. The Monterey Formation of California and the origin of its siliceous rocks, U.S. Geol. Surv. Prof. Pap., v. 213, p. 1-59.
Florke, O. W., Hollmann, R., von Rad, U., and Rösch, H., 1976. Intergrowth and twinning in opal-CT lepispheres, Contrib. Mineral. Petrol., v. 58, p. 235-242.

Heath, G. R. and Moberly, R., 1971. Cherts from the western Pacific, Leg 7, Deep Sea Drilling Project. In Winterer, E. L., Riedel, W. R., et al., Initial Reports of the Deep Sea Drilling Project, v. 7, Part 2: Washington (U.S. Government Printing Office), p. 991-1008.

Jones, J. B. and Segnit, E. R., 1971. The nature of opal. I. Nomenclature and constituent phases, J. Geol. Soc. Australia, v. 18 , p. $57-68$.

Kastner, M. and Keene, J. B., 1975. Diagenesis of pelagic siliceous oozes, Ninth Internat. Congr. of Sediment., Nice, v. 7, p. 89-99.

Kastner, M., Keene, J. B., and Gieskes, J. M., 1977. Diagenesis of siliceous oozes. I. Chemical controls on the rate of opal-A to opal-CT transformation - an experimental study, Geochim. Cosmochim. Acta, v. 41, p. 1041-1059.

Keene, J. B., 1975. Cherts and porcellanites from the North Pacific, Deep Sea Drilling Project Leg 32. In Larson, R. L., Moberly, R., et al., Initial Reports of the Deep Sea Drilling Project, v. 32: Washington (U.S. Government Printing Office), p. 429-507.

Lancelot, Y., 1973. Chert and silica diagenesis in sediments from the central Pacific. In Winterer, E. L., Ewing, J. I., et al., Initial Reports of the Deep Sea Drilling Project, v. 17: Washington (U.S. Government Printing Office), p. 377405.

Riech, V., 1978. Diagenesis of silica, zeolites and pyllosilicates in Sites 397 and 398. In Ryan, W. B. F., von Rad, U., et al., Initial Reports of the Deep Sea Drilling Project, v. 47, Part 2: Washington (U.S. Government Printing Office).

Riech, V. and von Rad, U., 1978. Eocene porcellanites and Early Cretaceous cherts from the western North Atlantic Basin. In Tucholke, B., Vogt, P., et al., Initial Reports of the Deep Sea Drilling Project, v. 43: Washington (U.S. Government Printing Office), p. 437-456.

von Rad, U. and Rösch, H., 1974. Petrography and diagenesis of deep-sea cherts from the Central Atlantic. In Hsü, K. J. and Jenkyns, H. C., (Eds.), Pelagic sediments: on land and under the sea, Spec. Publs. Int. Assoc. Sediment, v. 1, p. 327-347.

von Rad, U., Riech, V., and Rosch, H., 1978. Silica diagenesis in continental margin sediments off Northwest Africa. In Lancelot, Y., Seibold, E., et al., Initial Reports of the Deep Sea Drilling Project, v. 41: Washington (U.S. Government Printing Office), p. 879-906. 


\section{PLATE 1}

Figure 1 Slightly siliceous marl with burrows in which a distinct mass extinction parallel to the bedding under crossed nicols occurs. This phenomenon is possibly caused by authigenesis of silicates (montmorillonite, palygorskite) in the burrows. Authigenetic zeolitic material is also present in poorly preserved radiolarians, but the silica from dissolved siliceous particles was not precipitated as opal-CT (Sample 416A-3-2, $150 \mathrm{~cm}$; upper Oligocene).

Figure 2 This siliceous marl with foraminifers and opal-A replaced diatoms and radiolarians is barely diagenetically altered, but might be a good precursor sediment for future formation of porcellanites (Sample 415-5-3, $100 \mathrm{~cm}$; lower Miocene).

Figures 3, 4 Porcellanite with carbonate rhombs and poorly to moderately well preserved nannofossils, which are possibly silica-replaced and only visible on HFetched surfaces (4). An elemental determination by energy-dispersive $\mathrm{X}$-ray analysis shows that the nannofossils do not contain any calcium (Sample 370-5, CC; Oligocene).

Figures 5, 6 Lower Miocene opal-A-(5) and Hauterivian opalCT-preserved radiolarians. In Figure 6 only a few skeletons show details, whereas others are atypical lumps of opal-CT (Samples 415-4-5, $66 \mathrm{~cm}$, and $416 \mathrm{~A}-8-1,50 \mathrm{~cm})$.

Figure $7 \quad$ Sharp boundary between quartz chert (right) and porcellanitic precursor sediment (left) along a quartz veinlet. The porcellanite already contains many quartz nuclei (Sample 370-15-2, $140 \mathrm{~cm}$; middle Eocene).

Figure 8 Well-preserved and quartz-replaced radiolarian skeletons in $\mathrm{H}_{2} \mathrm{SiF}_{6}$ residues of a middle-Eocene silica-cemented conglomerate (Sample 370-12-2, $55 \mathrm{~cm})$. 
PLATE 1
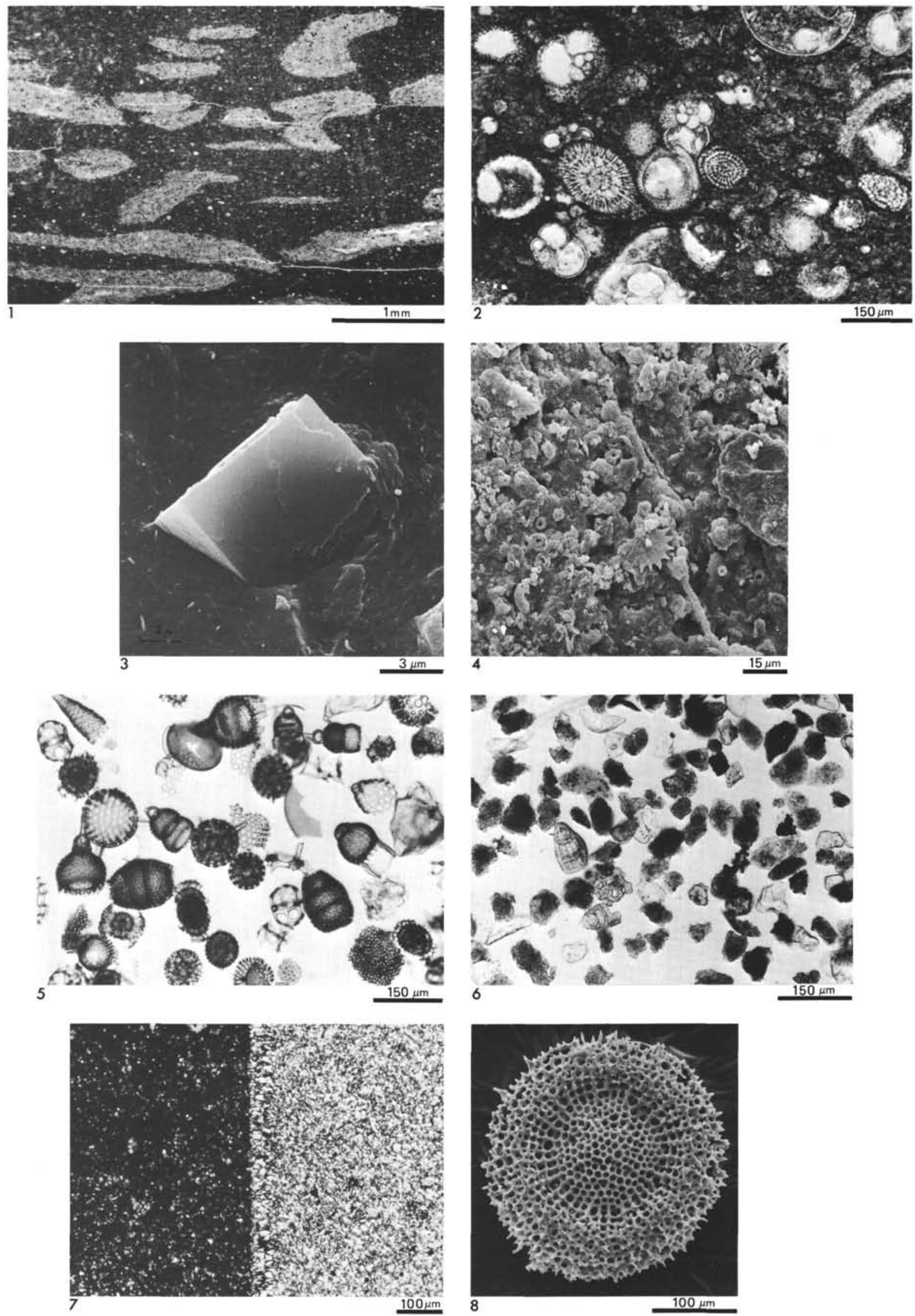